\title{
Pengembangan RPP dan LKPD Berbasis TPACK Pada Materi Garis dan Sudut untuk Meningkatkan Kemampuan Pemecahan Masalah Matematis
}

\author{
Nurjanah $^{1}$, Sutrisno $^{2}$, Jefri Marzal ${ }^{3}$ \\ 1, 2,3 Program Studi Magister Pendidikan Matematika, Fakultas Pascasrjana, Universitas jambi, \\ Jl. Jambi-Muaro Bulian KM.15 Mandalo Indah Muaro Jambi, Jambi, Indonesia \\ jnur5669@gmail.com
}

\begin{abstract}
This research on the development of technology-based pedagogy and content knowledge (TPACK) tools on line and angle material aims to develop TPACK-based lesson plans and worksheets to improve students' mathematical problem-solving skills on line and angle material. This study was designed using a 4D model development design and the research subject was class VII D MTs Negeri 5 Jambi City. The instruments used are student and teacher response questionnaires, observation sheets, assessment instruments for students' mathematical problem-solving abilities and TPACK integration instruments for teachers and expert validation sheets. The results showed that at the first meeting to the sixth meeting, it was included in the "good" category. The results of the average student learning evaluation are 67 which are categorized as "good". So, it can be concluded that the developed TPACK-based RPP and LKPD have increased students' learning activities on line and angle material, and are able to improve students' mathematical problem-solving abilities.
\end{abstract}

Keywords: TPACK, Lines and Angles, Mathematical Problem-solving Ability.

\begin{abstract}
Abstrak
Penelitian pengembangan perangkat berbasis Technology Pedagogy and Content Knowledge (TPACK) pada materi garis dan sudut ini bertujuan Mengembangkan RPP dan LKPD berbasis TPACK untuk meningkatkan kemampuan pemecahan masalah matematis peserta didik pada materi garis dan sudut. Penelitian ini dirancang dengan menggunakan desain pengembangan model 4D dansubjek penelitian adalah kelas VII D MTs Negeri 5 Kota Jambi. Adapun instrumen yang digunakan adalah angket tanggapan peserta didik dan guru, lembar observasi, instrumen penilaian kemampuan pemecahan masalah matematis peserta didik serta instrumen integrasi TPACK untuk guru dan lembar validasi ahli. Hasil penelitian menunjukan bahwa pada pertemuan I sampai pertemuan VI termasuk pada kategori "baik". Hasil evaluasi belajar peserta didik rata-rata 67 yang dikategorikan "baik". Sehingga, dapat disimpulkan bahwa RPP dan LKPD berbasis TPACK yang dikembangkan telah meningkatkan aktivitas pembelajaran peserta didik pada materi garis dan sudut, serta mampu meningkatkan kemampuan pemecahan masalah matematis peserta didik.
\end{abstract}

Kata kunci: TPACK, Garis dan Sudut, Kemampuan Pemecahan Masalah Matematis

Copyright (c) 2022 Nurjanah, Sutrisno, Jefri Marzal

$\triangle$ Corresponding author: Nurjanah

Email Address: jnur5669@gmail.com (Jl. Jambi-Muaro Bulian KM.15 Mandalo Indah Muaro Jambi, Jambi,) Received 27 September 2021, Accepted 21 October 2021, Published 06 January 2022

\section{PENDAHULUAN}

Proses pemecahan masalah matematis merupakan salah satu kemampuan dasar matematis yang harus dikuasai oleh peserta didik sekolah menengah. Dalam pemecahan masalah, peserta didik dituntut memiliki kemampuan menciptakan gagasan-gagasan atau cara-cara baru berkenaan dengan permasalahan yang dihadapinya.

Menurut Polya (1973), secara garis besar ada empat langkah utama dalam pemecahan masalah yaitu Understanding the problem (memahami masalah), Devising a Plan (merencanakan pemecahan masalah), Carrying out the Plan (melakukan rencana pemecahan masalah), dan Looking Back (memeriksa kembali pemecahan masalah). Ketika menyelesaikan suatu masalah terutama masalah matematika, peserta didik membutuhkan kreatifitas untuk berpikir secara ilmiah dan menggunakan nalar yang logis. Agar kemampuan pemecahan masalah matematis peserta didik dapat 
tercapai dengan maksimal. Maka, indikator dalam kemampuan pemecahan masalah matematis mengikuti tahapan dari pemecahan masalah.

Tetapi terkadang peserta didik mengalami hambatan dalam menyelesaikan permasalahan, apalagi jika permasalahan tersebut perlu memiliki visualisasi seperti halnya mempelajari bentukbentuk geometri. Salah satu materi yang ada kaitannya dengan geometri adalah materi garis dan sudut. Berdasarkan riset-riset sebelumnya menyatakan bahwa ada berbagai kesulitan belajar matematika peserta didik khususnya materi garis dan sudut. Argaswari dan Usodo (2015) mengemukakan bahwa peserta didik mengalami kesulitan dalam menyelesaikan permasalahan geometri khususnya sifat sudut yang terbentuk dari dua garis sejajar yang berpotongan dengan garis lain. Hal itu dikarenakan peserta didik kesulitan dalam menvisualisasikan bidang geometri, serta peserta didik cenderung menggeneralisasikan sifat-sifat geometri pada bidang geometri yang kurang tepat.

Perawansa dan Surya (2018) menambahkan bahwa peserta didik kesulitan dalam mengidentifikasi dan mengaitkan sifat yang satu dengan sifat yang lain, serta mereka lebih memilih menghafal rumus dan menggunakannya saja tanpa membiasakan untuk mengerjakan soal pembuktian rumus. Dari hasil wawancara dengan salah satu guru matematika MTs Negeri 5 Kota Jambi diperoleh informasi bahwa pada proses pembelajaran guru jarang menggunakan media pembelajaran yang interaktifdan pembelajaran tidak terpusat pada peserta didik, sehingga proses belajar yang diterapkan saat ini masih belum bermakna. Maka, perlu adanya alternatif proses belajar yang berpusat pada peserta didik dengan menggunakan TIK sebagai sumber belajar.

Pada kurikulum 2013, model discovery learningadalah salah satu model pembelajaran yang disarankan khususnya pada pembelajaran matematika. Menurut Teori dari Bruner yaitu tentang belajar dengan penemuan sangat cocok dengan pendekatan saintifik dimana pendekatan tersebut yang erat dikaitkan dengan kurikulum 2013. Jarwan (2018) dan Nurhasanah et.al (2018) dalam hasil risetnya, juga menyimpulkan bahwa melalui pembelajaran discovery learning, hasil belajar siswa mengalami peningkatan secara signifikan, sehingga mempengaruhi kemampuan pemecahan masalah dan kemampuan matematis peserta didik.

Selain model pembelajaran yang sesuai dengan permasalahan peserta didik, perlu adanya memilih TIK yang sesuai dengan materi dan aspek-aspek pedagogi. Menurut Damayanti et.al (2016) dan Noviafitri et.al (2016), kegiatan dan prestasi belajar peserta didik dengan pembelajaran berbantuan media yang disertai LKS penerapannya lebih baik daripada pembelajaran tanpa media dan LKS. Kedua penelitian tersebut masih belum tereksplorasi dengan baik dalam mengintegrasikan komponen teknologi, pedagogi dan materi dalam mengembangkan suatu perangkat pembelajaran. Sehingga, perlu dikembangkan sebuah perangkat pembelajaran dengan kerangka kerja yang menghubungkan antara teknologi, materi dan pedagogi dan interaksi antar komponen sebagai dasar pemilihan model pembelajaran maupun penyusunan perangkat pembelajaran. 
Integrasi antara teknologi, pedagogi dan materi dalam bentuk kerangka kerja yang dikembangkan oleh Koehler dan Mishra pada tahun 2006 dikenal dengan TPACK. TPACK (Technology Pedagogy and Content Knowledge) adalah kerangka kerja yang kompleks dan saling berhubungan antar komponen penyusunannya yaitu TK (Technology Knowledge), PK (Pedagogy Knowledge) dan CK (Content Knowledge), serta menggabungkan suatu rangkaian dalam pembelajaran dimana penguasaan teknologi secara terintegrasi tidak dapat dipisahkan satu sama lain dari komponen-komponen penyusunnya. Memilih TPACK sebagai kerangka pembelajaran dalam mengintegrasikan TIK, serta mengembangkan aktivitas pembelajaran yang situasional dan dinamis (aktif). Rahmini (2014) dan Najah (2018) telah melaksanakan riset tentang pengembangan perangkat pembelajaran berbasis TPACK, yang membedakan penelitian mereka dengan peneliti sekarang adalah pada materi, model pembelajaran dan kemampuan yang perlu ditingkatkan.

\section{METODE}

Penelitian ini adalah penelitian development perangkat pembelajaran pada materi garis dan sudut berbasis TPACK yang dipusatkan pada pengembangan rencana pelaksanaan pembelajaran (RPP) dengan menggunakan model discovery learningserta lembar kerja peserta didik (LKPD) berbasis TPACK. Rancangan pada penelitian ini menggunakan desain pengembangan model 4D yang disarankan oleh Thiagarajan (1974). Hal itu dikarenakan model 4D memiliki tahapan yang sistematis dan lebih rinci. Tahapan tersebut diantaranya define, design, develop, dan disseminate.

Jenis data pada penelitian ini adalah data kualitatif dari hasil validasi ahli, serta data kuantitatif didapat dari hasil kuesioner (angket)dan evaluasi belajar peserta didik. Instrumen yang digunakan dalam penelitian ini adalah lembar validasi, angket tanggapan peserta didik terhadap LKPD, angket tanggapan guru terkait RPP dan LKPD,lembar observasi aktivitas belajar peserta didik, soal-soal evaluasi belajar peserta didik, serta instrumen pengukuran TPACK guru yang dikembangkan oleh Sutrisno (2012). Data yang didapat dari angket dianalisis menggunakan numerical rating scale. Sedangkan, data hasil pengisian angket kerangka kerja TPACK dianalisis menggunakan path analysis dengan aplikasi SPSS Statistics 25. Kerangka berpikir yang digunakan oleh peneliti adalah 3 variabel yaitu (Technology Knowledge) TK, (Pedagogy Knowledge) PK, dan (Content Knowledge) CK mempengaruhi (Technology Pedagogy and Content Knowledge) TPACK baik secara langsung ataupun tidak langsung yang melalui (Technology Pedagogy Knowledge) TPK, (Technology Content Knowledge) TCK, dan (Pedagogy Content Knowledge) PCK. 
Prosedur pengembangan berdasarkan model 4-D disajikan dalam gambar berikut.

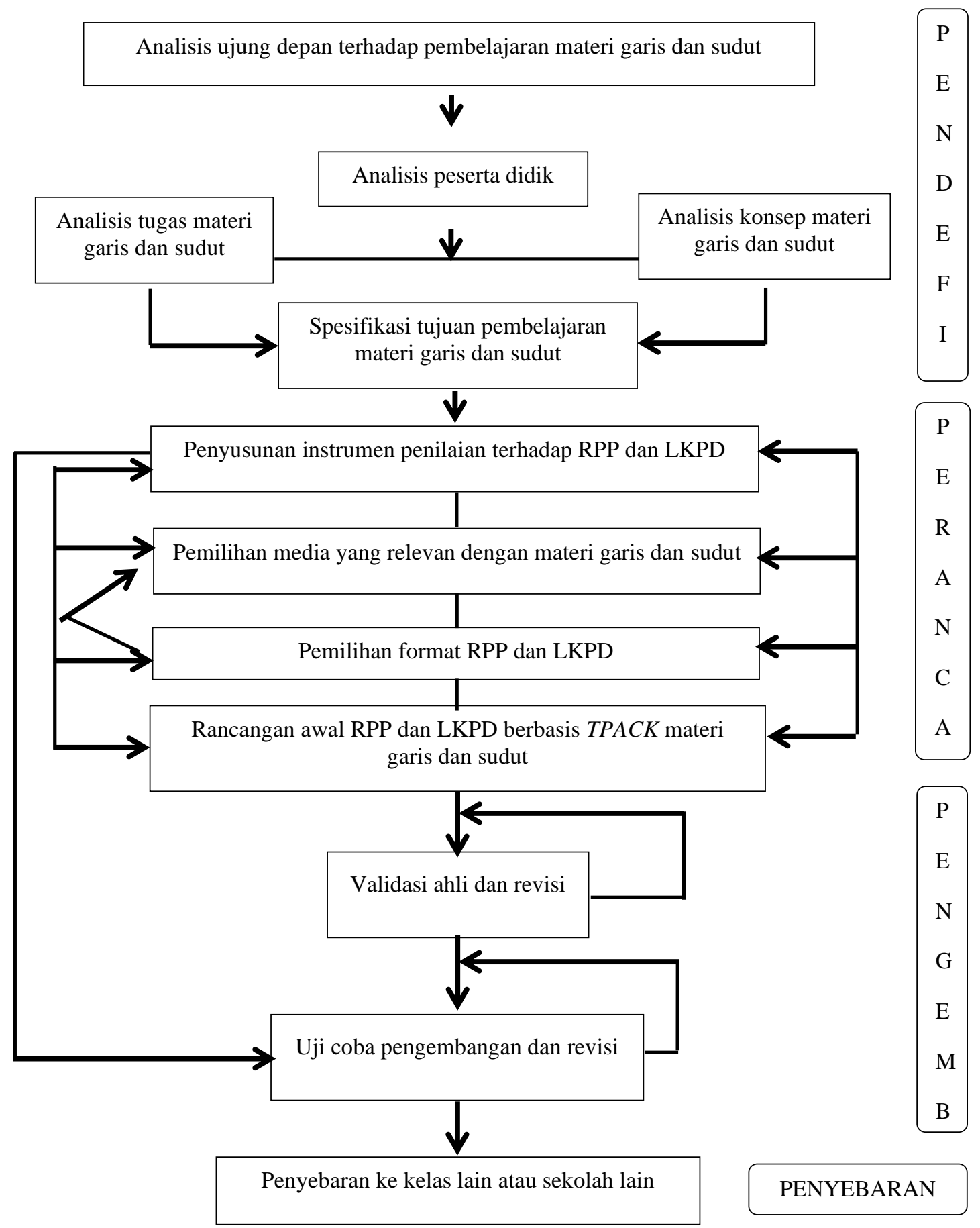

Gambar 1. Model Pengembangan Perangkat Pembelajaran pada Materi Garis dan Sudut Berbasis TPACK

\section{HASIL DAN DISKUSI}

\section{Hasil Penelitian}

Perangkat pembelajaran yang dikembangkan dalam penelitian ini adalah rencana pelaksanaan pembelajaran (RPP) yang disusun berdasarkan Permendikbud (2016) serta mencantumkan tahapan 
pembelajaran yang sesuai dengan tahapan model discovery learning. Didalam RPP terdapat 7 kali pertemuan yaitu 6 kali pertemuan membahas tentang garis dan sudut, sedangkan 1 kali pertemuan untuk evaluasi belajar peserta didik. Serta, lembar kerja peserta didik (LKPD) dibuat berdasarkan Depdiknas (2008) dan memuat komponen-komponenTPACK. Dikarenakan pembelajaran dilakukan secara online, maka video pembelajaran yang terdapat pada LKPD di upload ke youtube. Setelah video di upload ke youtube oleh guru, kemudian guru mengarahkan siswa melihat video yang telah di upload.

Produk penelitian berupa RPP dan LKPD yang dikembangkan sesuai dengan aspek-aspek pengukuran validitas yaitu telah memenuhi validitas desain dan validitas materi.Keoptimalan RPP dan LKPD dinilai dari 3 hal yaitu: 1) Keterlaksanaan RPP dan LKPD, 2) Tanggapan peserta didik terhadap LKPD dan 3) Tanggapan guru terhadap RPP, LKPD dan pelaksanaannya secara online. Berdasarkan uji coba kelompok besar diperoleh data hasil evaluasi belajar matematika peserta didik adalah 67kategori "Baik". Hasil analisis data tanggapan peserta didik terhadap LKPD diperoleh 12 peserta didik menjawab optimal dan 6 peserta didik menjawab cukup optimal. Sedangkan hasil analisis data tanggapan guru terhadap RPP, LKPD dan pelaksanaannya diperoleh rata-rata persentase $60,71 \%$ kategori “Optimal”.

Uji coba yang dilakukan dimulai dari uji coba perorangan, setelah memperoleh saran dan masukan dari peserta didik.Kemudian direvisi, selanjutnya dilakukan lagi uji coba kelompok kecil, dan dilanjutkan lagi uji coba kelompok besar.Dari hasil uji coba kelompok besar diperoleh data aktivitas belajar matematika secara online, tanggapan peserta didik terhadap LKPD dan kemampuan pemecahan masalah matematis.

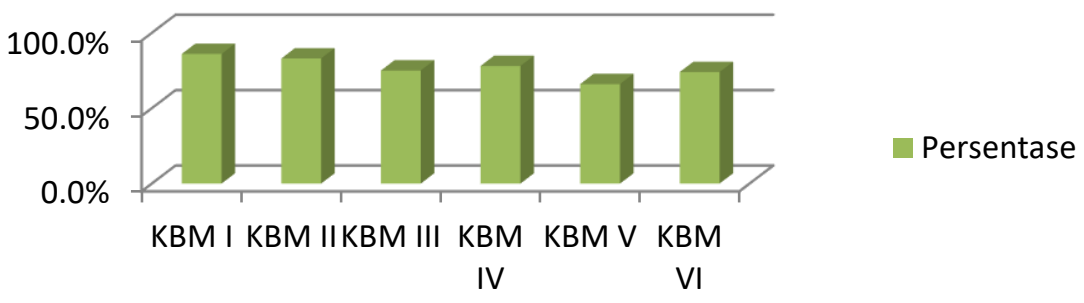

Grafik 1. Persentase Aktivitas Belajar Matematika Peserta Didik

Pada gambar 1 terlihat bahwapersentase aktivitas belajar matematikapeserta didikmengalami naik turun, dikarenakan beberapa peserta didik mengalami kesulitan ketika belajar online.Akan tetapi, Peserta didik tetap antusias dalam mengikuti kegiatan pembelajaran secara online. Rata-rata persentase aktivitas persentase dari pertemuan satu sampai pertemuan keenam adalah $77 \%$ termasuk kategori "optimal". Hal ini terlihat bahwa pembelajaran yang dilakukan secara onlinetelah mampu mengoptimalkan aktivitas pembelajaran matematika peserta didik. 
Dari angket yang telah diisi peserta didik terkait tanggapan peserta didik terhadap LKPD yang telah dibuat, secara umum memberikan tanggapan baik, ada6 peserta didik yang memberikan tanggapan cukup terhadap LKPD berbasis TPACK.

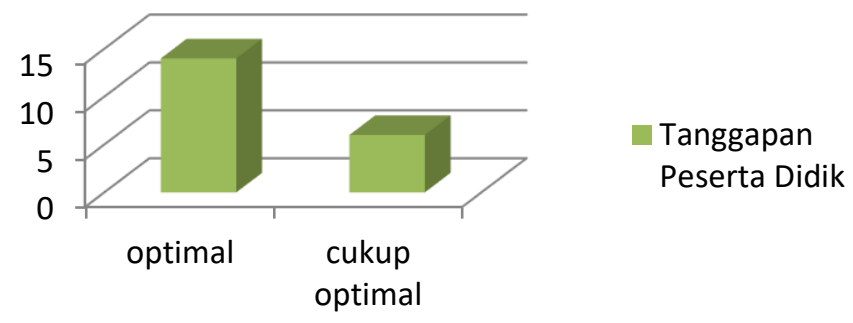

Grafik 2. Grafik kategori hasil angket tanggapan peserta didik

Pada gambar 2 memperlihatkan bahwa rata-rata peserta didikmerasa senang, termotivasi dan terbantu dalam memahami konsep serta dapatmenyelesaikansoal-soal yang ada terhadap pembelajaran berbasisTPACK.Peserta didikmenilai pembelajaran ini dengan cukup optimal, alasannya karena mereka kehabisan paket data dan ada materi pembelajaran yang masih kurang paham dikarenakan bingung dalam pengerjaannya.

Pengisian angket tanggapan guru matematika yang dilakukan oleh 7 orang. Hasil data yang diperoleh yaitu 46,4\% skor terendah, hal ini dikarenakan guru yang bersangkutan kurang menguasai $I T$, baik dalam hal membuat perencanaan ataupun pada pelaksanaan belajar mengajar. Sedangkan skor tertinggi adalah 78,6\%, perihal itu dikarenakan guru telah memiliki penguasaan $I T$ cukup baik sertatelah terbiasa memanfaatkanITpadapembelajaran.Tanggapan positif yang diberikan secara keseluruhan terhadap RPP dan LKPD adalah "optimal”.Berdasarkan hasil data tersebut dapat dikemukakan bahwa RPP dan LKPD yang dikembangkan cukup mudah dan bisa digunakan oleh guru. Berikut ini merupakan hasil analisis integrasi antar komponen TPACK.

Tabel 1. Korelasi antar komponen TPACK

\begin{tabular}{|c|c|c|c|c|c|c|c|c|}
\hline \multirow{4}{*}{$P K$} & & $P K$ & $T K$ & $C K$ & $T C K$ & $P C K$ & $T P K$ & TPACK \\
\hline & Pearson Correlation & 1 & ,589 &, $832^{*}$ & ,634 &, 455 & ,712 &, 531 \\
\hline & Sig. (2-tailed) & & , 164 &, 020 & , 126 & ,306 &, 073 & 220 \\
\hline & $N$ & 7 & 7 & 7 & 7 & 7 & 7 & 7 \\
\hline \multirow[t]{3}{*}{$T K$} & Pearson Correlation & ,589 & 1 &, 710 & $855^{*}$ &, $811^{*}$ & ,984** &, $887^{* * *}$ \\
\hline & Sig. (2-tailed) &, 164 & &, 074 & ,014 & ,027 &, 000 & ,008 \\
\hline & $N$ & 7 & 7 & 7 & 7 & 7 & 7 & 7 \\
\hline \multirow[t]{3}{*}{$C K$} & Pearson Correlation & $832^{*}$ & 7110 & 1 & ,583 & ,717 &, $812^{*}$ & ,564 \\
\hline & Sig. (2-tailed) & ,020 & ,074 & & 170 & ,070 & ,026 & 188 \\
\hline & $N$ & 7 & 7 & 7 & 7 & 7 & 7 & 7 \\
\hline \multirow[t]{3}{*}{$T C K$} & Pearson Correlation & ,634 & $855^{*}$ &, 583 & 1 &, 403 &, $869^{*}$ & $955^{* *}$ \\
\hline & Sig. (2-tailed) &, 126 & ,014 &, 170 & &, 370 &, 011 &, 001 \\
\hline & $N$ & 7 & 7 & 7 & 7 & 7 & 7 & 7 \\
\hline \multirow[t]{2}{*}{$P C K$} & Pearson Correlation &, 455 & ,811* &, 717 & ,403 & 1 &, $797^{*}$ & 495 \\
\hline & Sig. (2-tailed) & ,306 & ,027 & 070 & ,370 & & 032 & 259 \\
\hline
\end{tabular}


Pengembangan RPP dan LKPD Berbasis TPACK Pada Materi Garis dan Sudut untuk Meningkatkan Kemampuan Pemecahan Masalah Matematis, Nurjanah, Sutrisno, Jefri Marzal

\begin{tabular}{|l|l|r|r|r|r|r|r|r|}
\hline & $N$ & 7 & 7 & 7 & 7 & 7 & 7 & 7 \\
\hline \multirow{5}{*}{$T P K$} & Pearson Correlation &, 712 &, $984^{* *}$ &, $812^{*}$ &, $869^{*}$ &, $797^{*}$ & 1 &, $881^{* *}$ \\
\cline { 2 - 8 } & Sig. (2-tailed) &, 073 &, 000 &, 026 &, 011 &, 032 & &, 009 \\
\cline { 2 - 8 } & N & 7 & 7 & 7 & 7 & 7 & 7 & 7 \\
\hline \multirow{3}{*}{ TPACK } & Pearson Correlation & 531 &, $887^{* *}$ &, 564 &, $955^{* *}$ &, 495 &, $881^{* *}$ & 1 \\
\cline { 2 - 8 } & Sig. (2-tailed) &, 220 &, 008 &, 188 &, 001 &, 259 &, 009 & \\
\cline { 2 - 8 } & $N$ & 7 & 7 & 7 & 7 & 7 & 7 & 7 \\
\hline
\end{tabular}

*. Correlation is significant at the 0.05 level (2-tailed).

**. Correlation is significant at the 0.01 level (2-tailed).

Untuk melihat besarnya pengaruh antar komponen, maka dilakukan analisis regresi dengan menggunakan SPSS versi 25. Sehingga didapat:

1. Besarnya pengaruh $T K$ dan $C K$ terhadap $T C K$ adalah $73,2 \%$. Dengan kata lain besarnya pengaruh lain $\left(e_{1}\right)$ sebesar $100 \%-73,2 \%=26,8 \%$.

2. Besarnya pengaruh $T K$ dan $P K$ terhadap $T P K$ adalah $99,5 \%$. Dengan kata lain besarnya pengaruh lain $\left(e_{2}\right)$ sebesar $100 \%-99,5 \%=0,5 \%$.

3. Besarnya pengaruh $P K$ dan $C K$ terhadap $P C K$ adalah $58 \%$. Dengan kata lain besarnya pengaruh lain $\left(e_{3}\right)$ sebesar $100 \%-58 \%=42 \%$.

4. Besarnya pengaruh semua variabel terhadap $T P A C K$ dalam pembelajaran adalah 93,5\%. Dengan kata lain besarnya pengaruh lain $\left(e_{4}\right)$ sebesar $100 \%-93,5 \%=6,5 \%$.

\section{Diskusi}

Berdasarkan hasil penelitian pengembangan yang telah diuraikan, pengembangan RPP dan LKPD yang dilakukan dengan tahapan pengembangan model 4D dapat dikatakan valid, praktis dan efektif, serta diujicobakan pada kelompok besar kelas VII MTs Negeri 5 Kota Jambi. Produk akhir dari penelitian ini memiliki kelebihan-kelebihan, seperti memudahkan peserta didik dalam memperoleh suatu ilmu pengetahuan baru, memberikan pengalaman baru dalam proses belajar mengajar baik untuk peserta didik maupun guru, serta mengajak guru dalam mengembangkan perangkat pembelajaran menjadi lebih baik dan mudah digunakan khususnya yang melibatkan IT.

Selain memiliki kelebihan, produk yang dikembangkan juga memiliki kekurangan, yaitu bagi peserta didik akan kesulitan memahami materi pada LKPD, jika mereka tidak memiliki smartphone. Karena link materi pembelajaran dikirimkan melalui grup kelas.Sehingga, pembelajaran tidak tersampaikan dengan maksimal. Produk penelitian berupa rencana pelaksanaan pembelajaran (RPP) dan lembar kerja peserta didik (LKPD) yang dikembangkan sesuai dengan aspek-aspek pengukuran validitas yaitu telah memenuhi validitas desain dan validitas materi.RPP dan LKPD memenuhi validitas desain berarti dalam pengembangannya telah memperhatikan kriteria dalam mendesain sebuah produk.Sedangkan RPP dan LKPD memenuhi validitas materi berarti dalam pengembangannya telah didasarkan atas teori-teori yang dijadikan pedoman dalam perumusan atau penyusunan RPP dan LKPD. 
Hasil validasi dapat dijadikan acuan akan kualitas produk (Nurjanah et al., 2021). Berdasarkan saran dan masukan ahli materi yang memvalidasi produk dalam penelitian ini yang berupa rencana pelaksanaan pembelajaran (RPP) yang dikembangkan, ada beberapa revisi yang dilakukan oleh peneliti.

Pertama, menurut ahli materi perlu adanya tambahan komponen TPACK pada RPP agar terlihat jelas komponen apa saja yang digunakan pada kegiatan pembelajaran. Kedua, pada lembar validasi perlu ditambahkan indikator tentang tahapan model discoverylearning agar mempermudah validator untuk memeriksa setiap tahapan pada RPP. Ketiga, pada lembar validasi terdapat indikator "keabsahan", yang seharusnya indikator "bahasa". Karena disesuaikan dengan aspek yang perlu dinilai.

Produk selanjunya yang divalidasi oleh ahli materi adalah lembar kerja peserta didik (LKPD). Ada beberapa revisi yang dilakukan oleh peneliti seperti menambahkan pernyataan tentang manfaat digunakannya video pembelajaran pada lembar validasi dibagian "aspek yang dinilai", kemudian menambahkan kalimat perintah pada LKPD sebelum mengamati video pembelajaran. Serta, pada setiap pertemuan dalam LKPD dilengkapi dengan komponen-komponen TPACK.

Produk LKPD yang dikembangkan juga perlu divalidasi oleh ahli desain. Berdasarkan saran dan masukan ahli desain, ada beberapa revisi yang dilakukan oleh peneliti seperti menyesuaikan dengan komponen-komponen TPACK dan penyajian video pembelajaran harus diperjelas dengan kalimat yang sesuai dengan video yang akan dilihat.

Keoptimalan RPP dan LKPD diukur dari tiga hal (Rahmini, 2014) yaitu: 1) Keterlaksanaan RPP dan LKPD, 2) Tanggapan peserta didik terhadap LKPD dan 3) Tanggapan guru terhadap RPP, LKPD dan pelaksanaannya secara daring.Sebelum LKPD digunakan pada kelompok besar, maka perlu diujicobakan terlebih dahulu ke uji coba perorangan dan uji coba kelompok kecil.Uji coba perorangan dilakukan oleh 3 orang peserta didik yang dipilih secara acak.Sedangkan uji coba kelompok kecil dilakukan oleh 6 orang peserta didik. Berdasarkan saran dan masukan yang diberikan oleh peserta didik, ada beberapa revisi yang dilakukan, seperti perlu adanya video tambahan untuk penjelasan awal tentang cara pengisian LKPD pada setiap pertemuan. Serta pada pertemuan pertama di kegiatan 3, perlu adanya perbaikan dipeletakkan titik berwarna biru.

Setelah uji coba perorangan dan uji coba kelompok kecil dilakukan, langkah selanjutnya adalah mengujicobakan produk ke kelompok besar yang dilakukan pada kelas VII D MTs Negeri 5 Kota Jambi.Uji coba ini dilakukan pada bulan Februari secara daring dikarenakan masih dalam kondisi pandemi.Menurut Susilowati (2020) pembelajaran secara daring merupakan proses pembelajaran yang efektif dimasa pandemi, serta mendorong peserta didik untuk meningkatkan kemandirian dan keaktifan belajar.

Dari uji coba kelompok besar diperoleh data aktivitas pembelajaran secara daring, tanggapan peserta didik terhadap LKPD, tanggapan guru terhadap RPP dan LKPD yang digunakan, serta hasil 
evaluasi belajar peserta didik. Aktivitas pembelajaran yang dilakukan secara daring mengalami naik turun, dikarenakan beberapa peserta didik mengalami kesulitan ketika belajar daring, seperti kehabisan kuota internet.Akan tetapi, peserta didik tetap antusias dalam mengikuti kegiatan pembelajaran secara daring.Rata-rata persentase aktivitas persentase dari pertemuan satu sampai pertemuan keenam adalah $77 \%$ termasuk kategori “optimal”.Hal ini membuktikan bahwa pembelajaran yang dilakukan secara daring telah mampu mengoptimalkan aktivitas pembelajaran matematika peserta didik.Serta, rata-rata hasil evaluasi belajar peserta didik adalah 67 , dengan nilai tertinggi dan nilai terendah yang diperoleh adalah 83 dan 50 .

Berdasarkan angket yang telah diisi peserta didik terkait tanggapan peserta didik terhadap LKPD yang telah dibuat, secara umum memberikan tanggapan baik, ada 6 peserta didik yang memberikan tanggapan cukup terhadap LKPD berbasis TPACK.Hal ini menunjukkan bahwa rata-rata peserta didik merasa senang, termotivasi dan terbantu dalam memahami konsep serta dapat menyelesaikan soal-soal yang ada terhadap pembelajaran berbasis TPACK.Peserta didik menilai pembelajaran ini dengan cukup optimal, alasannya karena mereka kehabisan paket data dan ada materi pembelajaran yang masih kurang paham dikarenakan bingung dalam pengerjaannya.

Pengisian angket tanggapan guru matematika yang dilakukan oleh 7 orang. Hasil data yang diperoleh yaitu 46,4\% skor terendah, hal ini dikarenakan guru yang bersangkutan kurang menguasai IT, baik dalam hal membuat perencanaan ataupun pada pelaksanaan belajar mengajar. Sedangkan skor tertinggi adalah $78,6 \%$, perihal itu dikarenakan guru telah memiliki penguasaan IT cukup baik serta telah terbiasa memanfaatkan IT pada pembelajaran. Seperti halnya yang dikemukakan oleh Mishra dan Koehler (2008) bahwa proses pengajaran dan pembelajaran perlu memanfaatkan teknologi atau IT. Tanggapan positif yang diberikan oleh guru matematika terhadap RPP dan LKPD adalah “optimal”.Berdasarkan hasil data tersebut dapat dikemukakan bahwa RPP dan LKPD yang dikembangkan cukup mudah dan bisa digunakan oleh guru.

Merujuk pada usulan diagram jalur hubungan antara TK, CK, PK, PCK, TCK, TPK dan TPACK dalam Bab III dan instrumen yang telah dikembangkan, maka diperoleh suatu hubungan antara tiap-tiap komponen secara signifikan sesuai tabel 4.12. Dari tabel tersebut dapat dilihat bahwa TK mempunyai pengaruh langsung terhadap TPACK, tetapi juga mempunyai pengaruh tidak langsung terhadap TPACK yaitu dengan melalui TPK dan TCK.PK mempunyai pengaruh langsung terhadap CK. Serta, CK mempunyai pengaruh tidak langsung terhadap TPACK yaitu dengan melalui TPK. Semua komponen secara signifikan tidak mempengaruhi keberhasilan dalam mengintegrasikan TPACK. Hal ini sependapat dengan hasil penelitian dari Rahmini (2014), akan tetapi pada hasil penelitiannya PK tidak mempunyai pengaruh langsung terhadap CK, melainkan mempunyai pengaruh langsung dan tidak langsung terhadap TPACK. 


\section{KESIMPULAN}

Dari hasil penelitian pengembangan dan pembahasan, maka disimpulkan bahwa:

1. RPP yang dikembangkan dari silabus dan terkait dengan materi garis dan sudut. RPP disusun berdasarkan model Discovery Learning. Sedangkan, LKPD dibuat kemudian di share melalui grup whatshapp kelas dan video pembelajaran diupload melalui youtube. Dalam pembuatan RPP dan LKPD masing-masing dicantumkan dan disesuaikan dengan komponen-komponen TPACK.

2. Penerapan RPP dan LKPD pada materi garis dan sudut berbasis TPACK dilakukan secara online. Sebanyak 14 peserta didik memberi tanggapan dengan kategori optimal dan 6 peserta didik memberi tanggapan cukup optimal. Hasil dari tanggapan guru diperoleh rata-rata $60,71 \%$ dalam kategori "baik". Sedangkan, hasil observasi aktivitas belajarserta evaluasi belajar telah optimal.

3. Hasil dari pengukuran angket TPACK didapatkan hubungan yang signifikan antara PK dengan CK, TK dengan TCK, PCK, TPK dan TPACK. Serta, CK dengan PK dan TPK.

Saran yang diajukan terkait dengan hasil penelitian ini adalah RPP dan LKPD berbasis TPACK pada materi garis dan sudut dapat dikembangkan menggunakan dengan teknologi dengan format lain, seperti multimedia interaktif, game education, flippage ebook dengan software 3D page flip professional, dapat melalui web atau blog dan lain-lain untuk meningkatkan TK.

\section{REFERENSI}

Argaswari, D. P., \& Usodo, B. (2015). Analisis Kesulitan Belajar Geometri Kelas VII SMP. Seminar Nasional Matematika Dan Pendidikan Matematika. Yogyakarta: UNY.

Damayanti, S. Q., Mahardika, I. K., \& Indrawati, I. (2016). Penerapan Model Discovery Learning Berbantuan Media Animasi Macromedia Flash disertai LKS yang Terintegrasi dengan Multirepresentasi dalam Pembelajaran Fisika di SMA. Jurnal Pembelajaran Fisika, 4(4), 357364.

Depdiknas. (2008). Panduan Pengembangan Bahan Ajar. Jakarta: Departemen Pendidikan Nasional. Jarwan, J. (2018). Pengaruh Discovery Learning Terhadap Kemampuan Pemecahan Masalah dan Komonikasi Matematis Siswa. Proximal: Jurnal Penelitian Matematika Dan Pendidikan Matematika, 1(2).

Mishra, P., \& Koehler, M. J. (2008). Introducing technological pedagogical content knowledge. Annual Meeting of the American Educational Research Association, 1-16.

Najah, C. (2018). Pengembangan Perangkat Pembelajaran Berbasis TPACK Pada Materi Bangun Ruang Sisi Datar untuk Mengoptimalkan Kemampuan Komunikasi Tertulis Matematis Siswa SMP. Thesis, Universitas Jambi.

Noviafitri, S., Somakim, S., \& Hartono, Y. (2016). Pengembangan Lembar Kerja Siswa Berbasis Model Discovery Learning pada Pokok Bahasan Sudut Kelas VII [PhD Thesis]. Sriwijaya University. 
Pengembangan RPP dan LKPD Berbasis TPACK Pada Materi Garis dan Sudut untuk Meningkatkan Kemampuan

Nurhasanah, D. E., Kania, N., \& Sunendar, A. (2018). Penggunaan Model Pembelajaran Discovery Learning untuk Meningkatkan Kemampuan Pemecahan Masalah pada Siswa SMP. Jurnal Didactical Mathematics, 1(1), 301045.

Nurjanah, N., Sutrisno, S., \& Marzal, J. (2021). Pengembangan Perangkat Berbasis TPACK pada Materi Garis dan Sudut untuk Meningkatkan Kemampuan Pemecahan Masalah Matematis. Laplace: Jurnal Pendidikan Matematika, 4(2), 180-189.

Perawansa, F. I., \& Surya, E. (2018). Analisis Kesulitan Belajar Siswa Dalam Menyelesaikan Soal Materi Garis Dan Sudut.

Permendikbud. (2016). Salinan Lampiran Peraturan Menteri Pendidikan dan Kebudayaan Nomor 22, Tahun 2016, Tentang Standar Proses Pendidikan Dasar dan Menengah. Jakarta: Permendikbud. Polya, G. (1973). How to solve it second edition. Princeton University Press New Jersey.

Rahmini. (2014). Pengembangan Perangkat Pembelajaran Matematika Berdasarkan Kerangka Kerja TPACK Pada Materi Bangun Ruang Sisi Lengkung Untuk Mengoptimalkan Keterampilan Berfikir Kritis Siswa. Thesis, Universitas Jambi.

Susilowati, E. (2020). Bagaimana Pembelajaran Daring Di Tengah Wabah Covid 19 Melalui Grup WhatsApp? Jurnal Pendidikan Matematika Raflesia, 5(3), 1-25.

Sutrisno, S. (2012). Kreatif Mengembangkan Aktivitas Pembelajaran Berbasis TIK. Referensi.

Thiagarajan, S. (1974). Instructional development for training teachers of exceptional children: A sourcebook. 